Abstracta Iranica Abstracta Iranica

Revue bibliographique pour le domaine irano-aryen

Volume 28 | 2007

Comptes rendus des publications de 2005

\title{
Farhang-e nemād-hā va nešāne-hā dar andī̌se-ye Mowlānā. Tehrān, Sorūš, 1383/2004, xii + 888 p.
}

\section{Franklin Lewis}

\section{(2) OpenEdition \\ 1 Journals}

Édition électronique

URL : http://journals.openedition.org/abstractairanica/21201

DOI : 10.4000/abstractairanica.21201

ISSN : 1961-960X

\section{Éditeur :}

CNRS (UMR 7528 Mondes iraniens et indiens), Éditions de l'IFRI

\section{Édition imprimée}

Date de publication : 15 mai 2007

ISSN : 0240-8910

\section{Référence électronique}

Franklin Lewis, « Farhang-e nemād-hā va nešāne-hā dar andīše-ye Mowlānā. Tehrān, Sorūš, 1383/2004, xii + 888 p. », Abstracta Iranica [En ligne], Volume 28 | 2007, document 355, mis en ligne le 18 septembre 2007, consulté le 25 septembre 2020. URL : http://journals.openedition.org/ abstractairanica/21201; DOI : https://doi.org/10.4000/abstractairanica.21201

Ce document a été généré automatiquement le 25 septembre 2020.

Tous droits réservés 


\title{
Farhang-e nemād-hā va nešāne-hā dar andīše-ye Mowlānā. Tehrān, Sorūšs, 1383/2004, xii + 888 p.
}

\author{
Franklin Lewis
}

1 This reference work of "symbols and signs" in the poetry of Mowlānā Jalāl al-Dīn Rūmī contains over three hundred entries of widely varying length, alphabetically arranged. It is preceded by an introduction (pp. 1-8), and followed by a brief bibliography of 36 sources (pp. 887-88). Though described as a "dictionary" (farhang), it is neither particularly exhaustive, nor completely systematic. The headwords consist of nouns and proper names, many of which can be conceptually grouped as pertaining to flora and fauna; mythical creatures and literary figures; social characters and types; prophets and historical figures; nature, natural phenomena and the elements of the physical world; geography and topography; time and the seasons; religious occasions and symbols; human features; manmade objects; abstract concepts, and so on. Entries typically consist of a brief definition of the headword and a sentence or more explaining metaphorical and symbolic usages, amply illustrated by quotations (predominantly from the Matnavi, but drawing occasionally upon the Divān or the prose sources of Rūmī and Šams Tabrīzī), usually given at enough length to establish context. In the absence of any index or system of cross-references, readers may find that the headwords are not always the most intuitive or satisfactory choices of rubric: the pairs maǵz/qešr and șūrat/ma'ni lack their own entries, coming instead under the headword ' Pūst'; the word qiyāmat does not appear as a separate entry, but occurs as a subheading under the entry for 'Rūz' (pp. 483-4).

2 Rūmī has often been accused of presenting his teachings unsystematically, or in a dynamic and open-ended way that makes encapsulation and categorization difficult. This is neither the first nor the only work to attempt some systemization of Rümì's thought (see, e.g., Karīm Zamānī's topical Matnnavī commentary, Minnāgar-e 'ešq [Tehrān, Našr-e Ney, 1382/2003]), but approaching the task through symbols and metaphors seems methodologically promising, as it gives refreshing attention to the poet's 
language and its literary and symbolic dimensions, making for a sometimes helpful resource.

INDEX

Thèmes : 11.1.1. Littérature persane classique

\section{AUTEURS}

\section{FRANKLIN LEWIS}

University of Chicago 